\title{
Professional athletes have higher anxiety levels during COVID-19 outbreak compared to recreational athletes and sedentary people
}

\section{Profesyonel sporcular COVID-19 salgInı sIrasında rekreasyonel sporcular ve sedanter bireylere kıyasla daha kaygilı}

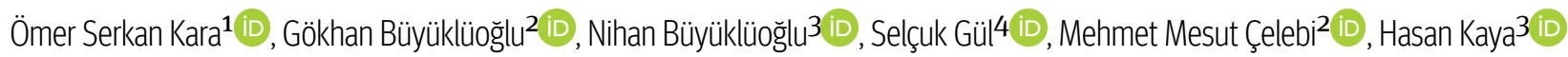 \\ ${ }^{1}$ Department of Sports Medicine, Faculty of Medicine, Hacettepe Universitty, Ankara, Turkey \\ ${ }^{2}$ Department of Sports Medicine, Faculty of Medicine, Ankara University, Ankara, Turkey \\ 3 Psychiatry Section, Ankara City Hospital, Ankara, Turkey \\ 4 Sports Medicine Section, Erzurum State Hospital, Erzurum, Turkey
}

\begin{abstract}
Objective: Although the COVID-19 outbreak affected almost all the people globally, the number of studies investigating the effects on professional athletes are very low. Therefore, we aimed to examine anxiety levels, mental toughness and daily habits of professional and recreational athletes during the early phase of the pandemic and compare these with sedentary control objects.
\end{abstract}

Materials and Methods: 634 participants were evaluated in April 2020 with an online survey consisted of sociodemographic data, exercise habits and outbreak-related questions, along with Turkish versions of Sports Mental Toughness Questionnaire (SMTQ) and State-Trait Anxiety Inventory (STAl). 329 of the participants were professional athletes, 135 were recreational athletes and 170 were sedentary people.

Results: Professional athletes (PROs) scored significantly higher $(p<0.017)$ than recreatio-nal athletes (RECRs) and sedentary people (SEDs) on SMTQ and State-Anxiety Scores, but not on Trait-Anxiety Score $(p>0.05)$. Besides, there were no significant differences between RECRs and SEDs on any of the scores $(p>0.05)$. For SMTQ scores; activity level, gender and age are found to be significantly predictive. State-Anxiety scores were only significantly correlated with activity levels, whereas, gender and age were significantly correlated with the Trait-Anxiety scores $(p<0.05)$.

Conclusion: Being a high-level professional athlete is related to higher state anxiety levels during the COVID-19 outbreak. Even though professional athletes are mentally tougher, which will help them cope with high anxiety levels, they may need extra psychologic support as long as the pandemic and restrictions continue.

\section{Keywords: professional athletes, physical activity, COVID-19, anxiety, mental toughness}

$\underline{\text { öz }}$

Amaç: COVID-19 salgını tüm insanları etkiledi, ancak profesyonel sporcular üzerindeki etkilerini araştıran çok az çalışma var. Bu nedenle pandeminin erken döneminde profesyonel ve rekreasyonel sporcuların anksiyete düzeylerini, mental dayanıklııklarını ve günlük alışkanlıklarını incelemeyi ve bunları sedanter bireylerle karşılaştırmayı amaçladık.

Gereç ve Yöntemler: 634 katııım 2020 yılı Nisan ayında sosyodemografik bilgiler, egzersiz alıșkanlıkları ve salgınla ilgili soruların yanı sıra Sporda Mental Dayanıkllık Ölçeği (SMDÖ) ve Durumluk-Sürekli Kaygı Envanterinin (DSKE) türkçe versiyonlarından oluşan çevrimiçi bir anket ile değerlendirildi. KatıIımciların 329'u profesyonel sporcu, 135'i rekreasyonel sporcu ve 170'i ise sedanter bireylerdi.

Bulgular: Profesyonel sporcular (PRO'lar) Mental Dayanıkllık ve Durumluk-Kaygı puan-larında rekreasyonel sporculardan (REKR'ler) ve sedanter kișilerden (SED'ler) anlamlı ölçüde daha yüksek $(p<0.017)$ puan almasına karşın Sürekli-Kaygı puanında anlamlı bir farklllık gözlenmedi ( $p>0.05)$. Ayrıca, REKR'ler ve SED'ler arasında puanların hiçbirinde anlamlı bir fark yoktu $(p>0.05)$. Toplam SMDÖ puanlarını belirleyici faktörler fiziksel aktivite düzeyi, cinsiyet ve yaș olarak saptandı. Durumluk Kaygı puanları sadece aktivite düzeyi, Sürekli Kaygı puanları ise cinsiyet ve yaș ile önemli ölçüde ilişkili bulun$\mathrm{du}(\mathrm{p}<0.05)$.

Sonuç: COVID-19 salgını sırasında, profesyonel sporcu olmak, daha yüksek durumluk kaygı düzeyi ile ilişkili bulundu. Profesyonel sporcular kaygıyla baş etmelerini kolaylaştıran yüksek mental dayanıklı̆̆g sahip olsalar da pandemi ve sportif faaliyetlerin kısıllamaları sürdükçe ilave psikolojik yardıma intiyaç duyabilirler.

Anahtar Sözcükler: profesyonel sporcular, fiziksel aktivite, COVID-19, anksiyete, mental dayanıklılk

\section{INTRODUCTION}

Novel coronavirus disease (COVID-19) spread all over the world and became a pandemic. People were encouraged to "stay at home" as much as possible, keep social distance and wear mask (1). Governments even had to impose curfe- 
ws, lockdowns and take similar measures to mitigate the spread of the outbreak. All these restrictions, the increasing number of cases and deaths on a global scale and the news in the media significantly increased anxiety and stress in society (2). Moreover, people have inevitably been spending more time at home and moving less than before (3).

Professional athletes differ from the normal population with their daily life, expectations and stressors (4-6). Suspending leagues, postponing mega sporting-events, restricting access to gyms, canceling team training and pay cuts are some of the major stressors encountered during the pandemic by this exclusive community (7). The impact of these limitations on the psychology of athletes cannot be denied and should be explored (8). Recreational athletes, on the other hand, diverge from professional athletes in terms of their approach to sports and the psychological effects of exercise on them $(9,10)$. For recreational athletes, training is a way of coping with stress $(9,11)$. Since these people mostly engage in physical activities in public spaces and gyms, they are significantly affected by the restrictions. Mitigation strategies also disrupt the routine daily physical activities of the sedentary people.

Regular physical activity is known to prevent the development of anxiety in the general population, reduce depression and improve mental well-being, sleep quality and cognitive functions (12). Chronic disease-related anxiety has been shown to decrease with exercise (13). Besides, individuals with a predisposition to anxiety spectrum disorders do not reach the disorder level if regular physical activity is maintained (14). Moreover, studies investigating effects of exercise on psychiatric symptoms during the pandemic also revealed supporting results (15-17). Although exercise is considered as one of the leading strategies for preventing mental disorders, the relationship between physical activity level and psychological parameters is a research subject yet to be clarified (18).

Anxiety can be considered as a situation or event-related transient state (e.g., state anxiety), or a relatively stable personality characteristic (e.g., trait anxiety) with the former being more likely to increase in life-threatening and harsh conditions (19). The pandemic is a challenging situation that increases anxiety in people, and it cannot be denied that psychological resilience affects this context. Psychological resilience is the ability to successfully overcome adversities and adapt despite the challenging conditions. It also has some features, such as maintaining healthy development and struggling with a negative situation (20). This concept, which is one of the main interests of psychology, has found its place in sports as "mental toughness". Whether mental toughness (MT) is a state-specific feature or a continuous trait in personality is still the subject of research (21). Nevertheless, it is known that MT of elite athletes who face more challenging conditions is higher than recreational athletes (22). Even though athletes are known to be mentally resilient to challenging situations, one should consider that the pandemic has its own features.

"Athlete's mental health" is a growing concern among the sports medicine community recently. Despite this, to the best of authors' knowledge, there are very few studies investigating the effects of the pandemic on professional athletes in current literature $(23,24)$. In these extraordinary conditions, which are the first time in the modern world with an unknown end, early research related to the exercise habits and relationship of those with psychological parameters may guide the measures to be taken to protect public health, either physically or mentally. Therefore, we aimed to investigate anxiety levels, mental toughness and daily habits of professional and recreational athletes (study groups) in the current situation and compare these with sedentary control subjects.

\section{MATERIALS and METHODS}

\section{Participants and Design}

After approval of the local ethics committee (no: İ4-245-20), a total of 634 participants were cross-sectionally evaluated in April 2020. Participants were consisted of 3 groups; professional (elite) athletes, recreational athletes, and sedentary people abbreviated as PROs, RECRs, and SEDs, respectively. PROs were competing at either the top-level national league or the first division for their sports branch, RECRs were participating in various types of sports for fun or general well-being, and SEDs were not participating in any kind of regular physical activity.

\section{Patient and Public Involvement}

Patients or the public were not involved in any part of this study.

\section{Methods}

The participants were evaluated anonymously with an online survey via Google Docs ${ }^{\mathrm{TM}}$ application. The survey consisted of 4 main sections; sociodemographic data-related, COVID-19-related, exercise-related (only for PROs and RECRs), and Turkish versions of Sports Mental Toughness Questionnaire (SMTQ) and State-Trait Anxiety Inventory (STAI) $(25,26)$.

Sociodemographic data consisted of age, gender, education level, marital status, number of children, presence of chronic illness, smoking, and alcohol consumption.

In the COVID-19-related part, information about if they live with a risk group individual for COVID-19, if they were diag- 
nosed with COVID-19, if any relative of theirs was diagnosed with COVID-19, video call numbers per day were obtained. Also, participants were asked to score their sleep from 1 to 10 with 10 representing their usual, pre-pandemic sleep.

The exercise-related part questioned the following, current weekly exercise time (hours/week) and exercise intensity (scored from 1 to 10 with 10 representing their overall exercise intensity before pandemic), current injury status (PROs only), pre-pandemic weekly exercise time (RECRs only). PROs were additionally asked if they were informed about the infection by their team doctor, if they received an exercise program from the team, how they think their performance would be affected by the course of the pandemic (both individually and as a team with separate questions).

SMTQ is a 4-point Likert-type questionnaire developed by Sheard, Golby, and Wersch in 2009 (27) consisting of 14 items. The sum of 14 items yields a total raw SMTQ score, which ranges from 14 to 56. The State-Trait Anxiety Inventory developed by Spielberger et al. (28) is also a 4-point Likert-type questionnaire used to measure the state and trait anxiety levels independently and contains a total of $40 \mathrm{qu}-$ estions, each consisting of 20 questions. The sum of items is calculated, then pre-determined constants ( 50 for the sta- te, 35 for the trait) are added to yield STAI scores. While interpreting both of the results, there are no cut-off values, but higher scores show greater MT and higher anxiety, respectively. Validity and reliability of Turkish version of both the SMTQ and STAI are demonstrated before by Pehlivan (26) and Oner et al.(25), respectively.

\section{Exclusion Criteria}

Participants younger than 18 years of age, professional athletes competing at a lower level than abovementioned and healthcare professionals were excluded from the study.

\section{Data Analyses}

Data were first screened for outliers and normality. Chi-square tests were used in the inter-group comparison of categorical variables, and categorical variables were expressed as numbers and percentages. $P$ values lower than 0.05 were considered as statistically significant. PROs were consisted of predominantly males $(\mathrm{n}=214,65.0 \%, \mathrm{p}<0.01)$ and SEDs were consisted of predominantly females $(n=104,61.2 \%$, $\mathrm{p}<0.01$ ). Therefore, we conducted multivariate analyses of co-variance (MANCOVA) to establish whether there were inter-group differences in 3 questionnaire scores with gender as a co-variant. In the comparison of 3 groups as for questionnaire scores, univariate analysis of variance (ANOVA)

\begin{tabular}{|c|c|c|c|c|c|c|c|c|}
\hline \multirow{3}{*}{ Characteristic } & \multicolumn{2}{|c|}{ Professional } & \multicolumn{2}{|c|}{ Recreational } & \multicolumn{2}{|c|}{ Sedentary } & \multicolumn{2}{|c|}{ Full sample } \\
\hline & n & $\%$ & n & $\%$ & n & $\%$ & $n$ & $\%$ \\
\hline & \multicolumn{8}{|c|}{ Gender } \\
\hline Female & 115 & 34.9 & 69 & 51,1 & 104 & 61,2 & 288 & 45,4 \\
\hline Male & 214 & 65.1 & 66 & 48.9 & 66 & 38,8 & 346 & 54,6 \\
\hline \multicolumn{9}{|l|}{ Marital status } \\
\hline Single & 86 & 26,1 & 11 & 8,1 & 39 & 22,9 & 136 & 21,4 \\
\hline Married/partnered & 243 & 73.9 & 124 & 91,8 & 131 & 77,1 & 498 & 78,6 \\
\hline Divorced/widowed & 0 & 0 & 0 & 0 & 0 & 0 & 0 & 0 \\
\hline Other & 0 & 0 & 0 & 0 & 0 & 0 & 0 & 0 \\
\hline \multicolumn{9}{|l|}{ Children } \\
\hline Yes & 62 & 18,8 & 4 & 2,9 & 0 & 0 & 66 & 10,4 \\
\hline No & 267 & 81,2 & 131 & 97,1 & 170 & 100 & 568 & 89,6 \\
\hline \multicolumn{9}{|l|}{ Chronic Disease } \\
\hline Yes & 17 & 5.1 & 16 & 11,9 & 29 & 17,1 & 62 & 9,8 \\
\hline No & 312 & 94.9 & 119 & 88,1 & 141 & 82,9 & 572 & 90,2 \\
\hline \multicolumn{9}{|l|}{ Smoking Status } \\
\hline Smoker & 70 & 21,3 & 26 & 19,3 & 46 & 27,1 & 142 & 22,4 \\
\hline Non-smoker & 259 & 78,7 & 109 & 80.7 & 124 & 72,9 & 492 & 77,6 \\
\hline \multicolumn{9}{|l|}{ Alcohol Consumption } \\
\hline Yes & 135 & 41,1 & 94 & 69.7 & 76 & 44.7 & 305 & 48,1 \\
\hline No & 194 & 58,9 & 41 & 30,3 & 94 & 55.3 & 329 & 51,9 \\
\hline \multirow{2}{*}{ Measure } & \multicolumn{2}{|c|}{ Professional } & \multicolumn{2}{|c|}{ Recreational } & \multicolumn{2}{|c|}{ Sedentary } & \multicolumn{2}{|c|}{ Full sample } \\
\hline & $M$ & SD & $M$ & SD & $M$ & SD & $M$ & SD \\
\hline Age & 25.3 & 5.53 & 25.3 & 5.52 & 27,2 & 8,13 & 25,8 & 6,39 \\
\hline Education Level & 14.5 & 2,11 & 16 & 1,48 & 15,8 & 1,95 & 15,2 & 2,06 \\
\hline
\end{tabular}

was used, and p values lower than 0.05 were considered as statistically significant. For further comparisons of possible binary combinations of groups, the post-hoc test was used, and $\mathrm{p}$ values lower than 0.017 were considered as statistically significant using the Bonferroni correction. For bivari- ate correlations, the Pearson correlation coefficient was used, and p values lower than 0.05 were considered as statistically significant. The calculations were performed using a statistical package program Statistical Package for Social Sciences (SPSS) version 22.0. 


\section{RESULTS}

\section{Descriptive Data}

The descriptive statistics for sociodemographic data, the data collected with the COVID-19 related section of our survey, and the questionnaires and sleep scores of participants are presented in Table-1, Table-2, and Table-3, respectively. The distribution of sport branches among professional athletes is shown in Fig.1.

\section{COVID-19-Related Issues}

Only 2 participants (both from SEDs) were diagnosed with COVID-19. The presence of an at-risk individual for COVID19 at home, and video call number per day (divided as $<1$ and $\geq 1$ ) did not significantly affect the questionnaire scores.

\section{Exercise-Related Issues}

There was a significant $(\mathrm{p}<0.01)$ difference between PROs and RECRs in current weekly exercise time $[M=8.1, S D=4.4$; $\mathrm{M}=4.5, \mathrm{SD}=2.9$, respectively, 95\% CI $(24.03,38.03)$ Cohen's $\mathrm{d}=1.14]$. While both groups' self-reported exercise intensity seemed to be decreased $(M=6.3, S D=1.9 ; M=5.9, S D=2.4$, respectively), there was no significant difference between the groups ( $\mathrm{p}=0.15)$. Comparing before and after the pandemic, there was a significant difference $(\mathrm{p}<0.01)$ in weekly exercise time for RECRs $[M=7.6, S D=4.3 ; M=4.5, S D=2.9$, respectively, 95\% CI $(2.35,3.85)]$. Among PROs, $37.4 \%$ of participants confirmed that they were informed by their team physicians about COVID-19, 60.2\% were thinking that their performance would be negatively affected, $66.2 \%$ were thinking that their team performance would be negatively affected, $60.8 \%$ declared they had been sent an exercise program for the "stay at home" period $(78.5 \%$ of these participants reported strict adherence to their program). Participants with an exercise program scored significantly $[\mathrm{p}<$ 0.05, 95\% CI (0.02, 0.93), Cohen's $d=0.32$ ] higher on the constancy subscale of SMTQ than the ones without it. Among the athletes who did not receive a training program from their team or coach, $73.6 \%$ stated that they had been exercising in a serious manner at least for a few days a week. Injury status at the time of the pandemic (recorded as injured or not) was not associated with state anxiety scores $(\mathrm{p}=0.21)$.

\begin{tabular}{|c|c|c|c|c|c|c|c|c|}
\hline \multirow{3}{*}{$\begin{array}{l}\text { Questions } \\
\text { Compliance to "Stay Home" Recommendatic }\end{array}$} & \multicolumn{2}{|c|}{ Professional } & \multicolumn{2}{|c|}{ Recreational } & \multicolumn{2}{|c|}{ Sedentary } & \multicolumn{2}{|c|}{ Full sample } \\
\hline & $\mathbf{n}$ & $\%$ & $\mathbf{n}$ & $\%$ & $\mathbf{n}$ & $\%$ & $\mathrm{n}$ & $\%$ \\
\hline & & & & & & & & \\
\hline Compliant & 310 & 94,2 & 119 & 88,1 & 150 & 88,2 & 579 & 91,3 \\
\hline Non-compliant & 19 & 5,8 & 16 & 11,9 & 20 & 11,8 & 55 & 8,7 \\
\hline \multicolumn{9}{|l|}{ With Whom The Participant Lives } \\
\hline With someone & 309 & 93,9 & 120 & 88,8 & 153 & 90 & 582 & 91,8 \\
\hline Alone & 16 & 4.8 & 15 & 11,2 & 17 & 10 & 48 & 7,6 \\
\hline At team facility & 4 & 1,3 & 0 & 0 & 0 & 0 & 4 & 0,6 \\
\hline \multicolumn{9}{|c|}{ Existence of at-risk population for COVID-19 at home } \\
\hline Yes & 116 & 35,2 & 53 & 39,2 & 84 & 49,4 & 253 & 39,9 \\
\hline No & 213 & 64,8 & 82 & 60,8 & 86 & 50,6 & 381 & 60,1 \\
\hline \multicolumn{9}{|l|}{ Diagnosis of COVID-19 in participant } \\
\hline Yes & 0 & 0 & 0 & 0 & 2 & 1,2 & 2 & 0,3 \\
\hline No & 329 & 100 & 135 & 100 & 168 & 98,8 & 632 & 99,7 \\
\hline \multicolumn{9}{|l|}{ Diagnosis of COVID-19 in participant's relatives } \\
\hline Yes & 20 & 6,1 & 5 & 3.7 & 11 & 6.5 & 36 & 5,7 \\
\hline No & 309 & 93.9 & 130 & 96,3 & 159 & 93.5 & 598 & 94.3 \\
\hline
\end{tabular}

Table 3. Descriptives of Scales and Sleep Scores

\begin{tabular}{|c|c|c|c|c|c|c|}
\hline \multirow[t]{2}{*}{ Measure } & \multicolumn{2}{|c|}{ Professional } & \multicolumn{2}{|c|}{ Recreational } & \multicolumn{2}{|c|}{ Sedentary } \\
\hline & $M$ & SD & $M$ & SD & $M$ & SD \\
\hline State Anxiety Score (STAS) & 46,1 & 6,01 & 44.4 & 4.54 & 44.3 & 6.33 \\
\hline Trait Anxiety Score (TRAS) & 45,8 & 6.31 & 45.9 & 6.59 & 46.7 & 6.57 \\
\hline SMTQ & 41,1 & 6,01 & 37.0 & 6.79 & 36,0 & 6,80 \\
\hline Confidence & 15,4 & 2,91 & 14.2 & 2.99 & 14,1 & 3.31 \\
\hline Constancy & 13,6 & 2,05 & 12.0 & 2.41 & 11,7 & 2,46 \\
\hline Control & 12,0 & 2,95 & 10.7 & 2.94 & 10,1 & 3,02 \\
\hline Sleep Score & 5,8 & 2,63 & 6.51 & 2.36 & 5.9 & 2,40 \\
\hline
\end{tabular}

M: Mean, SD: Standard Deviation, SMTQ: The Sports Mental Toughness Questionnaire

Kruskal Wallis Test $p$ values for STAS: 0.001, for TRAS: 0.198, for SMTQ and its subscales: <0.001, for Sleep Score: 0.056 


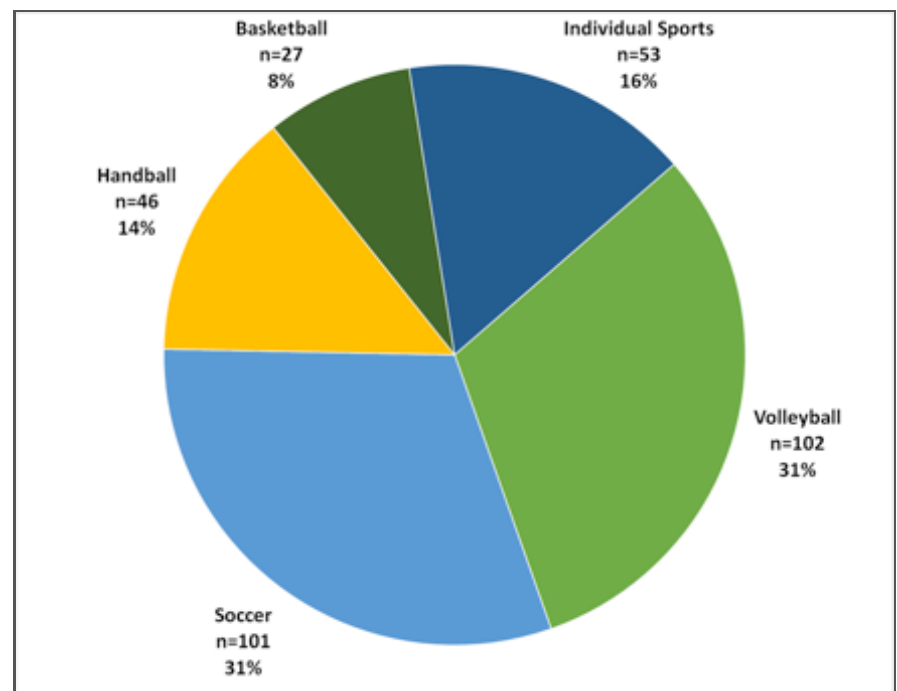

Figure 1. Pie chart demonstrating the distribution of sport branches among professional athletes

\section{Questionnaire and Sleep Scores}

The MANCOVA for groups with gender as a co-variate was significant for questionnaires (Wilks' $\mathrm{k}=0.97, \mathrm{p}<0.01$ ). The follow-up univariate analysis of variance and post-hoc analyses showed that PROs scored significantly higher than RECRs and SEDs on SMTQ [ $p<0.017$, Cohen's $d=0.08$ and $0.10,95 \%$ CI $(2.52,5.65)$ and $(3.65,6.55)$, respectively] and State-Anxiety Scores $[\mathrm{p}<0.017$, Cohen's $\mathrm{d}=0.03$ and 0.02 , $95 \%$ CI $(0.28,3.14)$ and $(0.52,3.16)$, respectively], but not on Trait-Anxiety Score. Besides, there were no significant differences between RECRs and SEDs on any of the scores.

Due to the differences between three groups in the questionnaire scores, a "groups by genders" MANOVA was conducted. Both the activity level and the gender have significant main effect (Wilks' $\mathrm{k}=0.89, \mathrm{p}<0.01$; Wilks' $\mathrm{k}=0.95$, $\mathrm{p}<0.01$, respectively), yet the interaction effect (Wilks' $\mathrm{k}=0.99, \mathrm{p}=0.41$ ) wasn't significant. The follow-up univariate analysis of variance showed that the males scored significantly higher ( $\mathrm{p}<0.05$, Cohen's $\mathrm{d}=0.05)$ on SMTQ scores and significantly lower $(\mathrm{p}<0.05$, Cohen's $\mathrm{d}=0.03)$ on Trait-Anxiety scores. Besides, there were no significant differences between genders on State-Anxiety scores.

We conducted a linear regression analysis to ascertain the relationship between possible predictors (activity level, gender, and age) and the scores. For SMTQ scores; activity level, gender, and age significantly predicted total score (DR2=0.11, b=-0.30; DR2=-0.04, b=0.20; DR2=0.01, b=0.12, respectively). For State-Anxiety scores; only activity level significantly predicted the score ( $\mathrm{DR} 2=0.02, \mathrm{~b}=-0.14)$. For Trait-Anxiety scores; gender and age significantly predicted the score (DR2=0.03, $b=0.17 ; D_{2}=0.01, b=-0.11$ ).
For Trait-Anxiety scores, there was a significant $(\mathrm{r}=0.42$, $\mathrm{p}<0.01)$ positive correlation with State-Anxiety scores, and a significant $(\mathrm{r}=-0.36, \mathrm{p}<0.01)$ negative correlation with SMTQ scores.

There was no significant difference between groups or genders in sleep scores ( $\mathrm{p}=0.56$ and $\mathrm{p}=0.48$, respectively), but sleep scores positively correlated with SMTQ scores $(r=0.10$, $\mathrm{p}<0.01)$.

\section{DISCUSSION}

The COVID-19 outbreak has affected our lives in every aspect, and its consequences are accordingly global, in terms of mental health. Anxiety has been one of the anticipated results of such global incidences (29). In our study, we aimed to investigate anxiety levels and MT, the relationship and differences between them among professional athletes, recreational athletes and sedentary individuals during the early phase of COVID-19 pandemic. We hypothesized that professional athletes would differ from other groups in terms of anxiety and mental toughness levels, and yielded accordingly.

\section{State and Trait Anxiety Scores}

Evaluation of general anxiety levels before the pandemic (trait-anxiety) and current anxiety levels during the outbreak (state-anxiety) were conducted by using STAI. In our study, the state anxiety scores were interpreted as one of the mental outcomes of the COVID-19 outbreak. PROs had the highest scores, but there was no significant difference between RECRs and SEDs, or genders. There might be several reasons for PROs having higher state-anxiety. The first confirmed COVID-19 case in Turkey was on 11 March 2020. Nevertheless, neither professional leagues were suspended nor competitions were canceled; thus, athletes still participated in matches until 19 March 2020. It means that athletes somewhat encountered the risk of transmission. Although $80 \%$ of the COVID-19 cases reported were mild in severity(30), pneumonia is the most frequent severe presentation of the disease and long-term outcomes are unknown yet. From the sports medicine aspect, pulmonary complications are always possible, but not likely, as most of the elite athletes are young and do not have comorbidities. However, severe pulmonary involvement could compromise an athlete's performance capacity due to pulmonary fibrosis $(31,32)$. On the other hand, the suspension of leagues and cancellation of matches also took elite athletes apart from their regular training routine and social environment. The emergence of the pandemic in a period when contract renewal and transfer negotiations would take place and the championship race would reach the final result, along with the uncertainty of when normalization would begin, might have 
caused additional stress $(8,33)$. Economic, occupational, health-related, and social concerns altogether could have increased anxiety in PROs during the COVID-19 outbreak (8).

Regarding trait-anxiety, our results showed that females and younger participants had higher scores overall, whereas PROs, RECRs, and SEDs have not differed significantly. Professional athletes could be expected to have lower traitanxiety scores while considering the protective effect of regular physical activity from anxiety. However, the pandemic has been going on for two months at the time we collected the data, and this could, and this could have affected the mindset of participants answering the questions blurring the lines between trait and state anxiety items. Also, a recent meta-analysis (34) on anxiety determinants in athletes from different competitive levels demonstrated that athletes and non-athletes had no differences in anxiety profiles, and ascertained that females, younger athletes, and injured athletes had higher anxiety levels, comparable to our findings.

Senisik et al. conducted a similar study where they investigated the effects of isolation on mental health and found that athletes had lower anxiety and depression symptoms compared to non-athletes (23). In terms of anxiety levels, the different results might be due to the time-period, which was two months later than our study, so with the passage of time adaptation might have come along and anxiety might have subsided. Another survey on athletes' mental health during the pandemic was conducted by Pillay et al. (24), in which they investigated only depressive symptoms in elite and semi-elite athletes and found that $52 \%$ of athletes felt depressed at some time. Comparable to our results, they also found lifestyle and sleep-wake cycle disturbances in athletes.

\section{Mental Toughness Scores}

Our research demonstrated that males, older participants, and professional athletes had higher MT scores, whereas there was no significant difference between RECRs and SEDs. Nicholls et al. (35) concluded that males had higher total MT scores than females, age and years of experience predicted higher scores of MT. With regard to age and MT, many studies showed that older age was both related and predicted higher MT $(27,35,36)$. Gaining experience and biological changes might be responsible for this. MT scores may suggest some state-specific features of a person, as well as a personality trait (21). When described as a state feature, MT consists of reactions that individuals form to stay calm and stable when they encounter stress or crisis. When defined as a persistent mental state or personality trait, MT is associated with being tough and durable, matu- re, practical, self-confident and achieving success through effort in adverse conditions (37). While Clough et al. (38) have suggested that MT is a trait-like personality characteristic, some authors have suggested genetic links $(39,40)$. Both genetic studies on MT concluded that MT is partly inherited, but also affected by environmental conditions, so it can partially change in time or as a response to events. Still, there is no definite conclusion as to whether MT is a continuous feature or a feature that varies depending on the situation. Considering our study was cross-sectionally designed, it would be inappropriate to comment on how MT scores affected by the pandemic. However, the comparison of both study groups with sedentary people, to the best of our knowledge, for the first time in the literature, along with the total number of participants, are some of the strengths of this study.

\section{Current Status and Exercise Habits}

In the current state of this pandemic, living with someone at-risk for COVID-19 (e.g., hypertension, COPD and older age) could be considered as a factor that can affect anxiety levels, but our study did not support that. Presumably, participants had other sources of anxiety rather than living with someone at higher risk, such as career issues and economic concerns. Moreover, in terms of social support, video calls were considered as a coping strategy with stress and anxiety, but anxiety levels were not significantly associated with these factors, as well. Accordingly, video calls might not be a robust anxiety-reducing factor alone.

One of the strengths of our study is that we have reached 329 elite athletes across the country, a considerable amount of top tier and first division players of all popular sports, particularly soccer and volleyball (Fig.1). We revealed that most of the elite athletes (6o.8\%) were sent a home exercise program by their staff (e.g., team, coach and athletic trainer). A vast majority of the participants (78.5\%) to whom a program was provided have strictly adhered to that program. Getting an exercise program from the staff could have implemented the idea of constant monitoring by the team, and thus made the athletes feel valued, supported, and perseverant. This could be the reason for increased "constancy" subscale scores of MT within the group participating an exercise program. Also, $73.6 \%$ of elite athletes without any provided program stated that they are exercising in a serious manner at least a few times a week. This commitment to exercise among PROs can be considered as another hallmark of qualification of the study population. Still, the decrease in self-reported exercise intensity of PROs should be considered by staff, especially when planning the proper training routine after the pandemic to decrease the devastating effects of detraining. 


\section{Limitations}

One of the limitations of our study was its cross-sectional design. It could provide more precise results in a prospective design. Secondly, an online survey is always a constraint; a face-to-face study could have been more reliable because some of the questions might have been answered without fully understanding. Speaking of reliability, applying scales comes with the limitation of trying to fit many different individuals into the same concept. It is difficult to measure an abstract concept within a variety of people. Finally, the self-reported measures could cause the athletes to have not been entirely honest with their responses due to the stigma attached to mental health. However, it is assumed that anonymity eliminated this concern.

\section{CONCLUSION}

Our study was among the first studies to evaluate the elite athletes during the COVID-19 pandemic in regards to the psychological outcomes. This study showed that at the beginning of the COVID-19 outbreak, being a high-level professional athlete was related to higher state anxiety levels, most probably due to multiple reasons discussed above. Further research is needed to assess the psychological impacts of the pandemic on the elite athletes and to guide the management of them. When we adapt to the current situation, the consequences of this pandemic in terms of athletes' mental health should be assessed and supported by mental health care providers, preferably experienced in sport psychology.

\section{Acknowledgements / Teşekkür}

The authors thank Dr.İsmail Kaya from Gülhane Training and Research Hospital, Ankara and Dr.Uğur Diliçıkık from İstanbul Başakşehir City Hospital, İstanbul for their assistance during the data collection, and Yank1 Çobanoğlu from Ayndo, Netherlands and Deniz Özcan from Distant Tech, Ankara for their assistance in editing the manuscript. No funding was received related to this article.

\section{Conflict of Interest / Çıkar Çatışması}

The authors declared no conflicts of interest with respect to authorship and/or publication of the article.

\section{Financial Disclosure / Finansal Destek}

The authors received no financial support for the research and/or publication of this article.

\section{REFERENCES}

1. Ebrahim SH, Ahmed QA, Gozzer E, Schlagenhauf P, Memish ZA. Covid-19 and community mitigation strategies in a pandemic. BMJ. 2020;368:m1066.

2. Wang T, Du Z, Zhu F, Cao Z, An Y, Gao Y, et al. Comorbidities and multi-organ injuries in the treatment of COVID-19. Lancet. 2020;395(10228):e52.

3. Hall G, Laddu DR, Phillips SA, Lavie CJ, Arena R. A tale of two pandemics: How will COVID-19 and global trends in physical inactivity and sedentary behavior affect one another? Prog Cardiovasc Dis. 2020;50033-0620(20)30077-3.

4. Keaney LC, Kilding AE, Merien F, Dulson DK. The impact of sport related stressors on immunity and illness risk in team-sport athletes. J Sci Med Sport. 2018;21(12):1192-9.
5. Bauman NJ. The stigma of mental health in athletes: Are mental toughness and mental health seen as contradictory in elite sport? Br J Sports Med. 2016;50(3):135-6.

6. Reardon CL, Hainline B, Aron CM, Baron D, Baum AL, Bindra A, et al. Mental health in elite athletes: International Olympic Committee consensus statement (2019). Br J Sports Med. 2019;53(11):667-99.

7. Schinke R, Papaioannou A, Henriksen K, Si G, Zhang L, Haberl P. Sport psychology services to high performance athletes during COVID-19. Int J Sport Exerc Psychol. 2020;18(3):269-72.

8. Mann RH, Clift BC, Boykoff J, Bekker S. Athletes as community; Athletes in community: Covid19, sporting mega-events and athlete health protection. Br J Sports Med. 2020;54(18):1071-1072.

9. De La Vega R, Parastatidou IS, Ruíz-Barquín R, Szabo A. Exercise addiction in athletes and leisure exercisers: The moderating role of passion. J Behav Addict. 2016;5(2):325-31.

10. Bär KJ, Markser VZ. Sport specificity of mental disorders: The issue of sport psychiatry. Eur Arch Psychiatry Clin Neurosci. 2013;263(SUPPL.2):205-10.

11. Allegre B, Souville M, Therme P, Griffiths M. Definitions and measures of exercise dependence. Addict Res Theory. 2006;14(6):631-46.

12. Warburton DER, Nicol CW, Bredin SSD. Health benefits of physical activity: The evidence. Cmaj.2006;174(6):801-9.

13. Herring MP, O'Connor PJ, Dishman RK. The effect of exercise training on anxiety symptoms among patients: A systematic review. Arch Intern Med. 2010;170(4):321-31.

14. Kandola A, Vancampfort D, Herring M, Rebar A, Hallgren M, Firth J, et al. Moving to Beat Anxiety: Epidemiology and Therapeutic Issues with Physical Activity for Anxiety. Curr Psychiatry Rep. 2018;20(8):63.

15. Maugeri G, Castrogiovanni P, Battaglia G, Pippi R, D’Agata V, Palma A, et al. The impact of physical activity on psychological health during Covid-19 pandemic in Italy. Heliyon. 2020;6(6):e04315.

16. Jacob L, Tully MA, Barnett Y, Lopez-Sanchez GF, Butler L, Schuch F, et al. The relationship between physical activity and mental health in a sample of the UK public: A cross-sectional study during the implementation of COVID-19 social distancing measures. Ment Health Phys Act. 2020;19:100345.

17. Schuch FB, Bulzing RA, Meyer J, Vancampfort D, Firth J, Stubbs B, et al. Associations of moderate to vigorous physical activity and sedentary behavior with depressive and anxiety symptoms in self-isolating people during the COVID-19 pandemic: A cross-sectional survey in Brazil. Psychiatry Res. 2020;292:113339.

18. Arango C, Díaz-Caneja CM, McGorry PD, Rapoport J, Sommer IE, Vorstman JA, et al. Preventive strategies for mental health. The Lancet Psychiatry. 2018;5(7):591-604.

19. Spielberger CD, Reheiser EC. Measuring anxiety, anger, depression, and curiosity as emotional states and personality traits with the STAI, STAXI and STPI. Comprehensive Handbook of Psychological Assessment Vol. 2 Personality Assessment. Hoboken, NJ, US: John Wiley \& Sons Inc; 2004. p. 70-86.

20. Masten AS, Coatsworth JD. The Development of Competence in Favorable and Unfavorable Environments: Lessons from Research on Successful Children. Am Psychol. 1998;53(2):205220.

21. Gucciardi DF, Hanton S, Gordon S, Mallett CJ, Temby P. The Concept of Mental Toughness: Tests of Dimensionality, Nomological Network, and Traitness. J Pers. 2015;83(1):26-44.

22. Collins D, MacNamara Á. The Rocky Road to the Top. Sport Med. 2012:42(11):907-14.

23. Şenışık S, Denerel N, Köyağasıoğlu 0, Tunç S. The effect of isolation on athletes' mental health during the COVID-19 pandemic. Phys Sportsmed. 2020;00(00):1-7.

24. Pillay L, Janse van Rensburg DCC, Jansen van Rensburg A, Ramagole DA, Holtzhausen L, Dijkstra HP, et al. Nowhere to hide: The significant impact of coronavirus disease 2019 (COVID-19) measures on elite and semi-elite South African athletes. I Sci Med Sport. 2020;23(7):670-9.

25. Oner N, Le Compte A. Durumluk-Surekli kaygi envanteri el kitabi. Istanbul: Boğaziçi Yayinları. Istanbul: Bogaziçi Universitesi; 1985.

26. Pehlivan H. Sporda Mental Dayanıkııık Ölçeği Uyarlama: Geçerlik ve Güvenirlik Çalışması. Celal Bayar Üniversitesi; 2014.

27. Sheard M, Golby J, Van Wersch A. Progress toward construct validation of the Sports Mental Toughness Questionnaire (SMTQ). Eur J Psychol Assess. 2009;25(3):186-93.

28. Teichman Y, Malineck F. Manual for the Hebrew state-trait anxiety inventory. Palo Alto, CA Consult Psychol Press. 1978;

29. Torales J, O'Higgins M, Castaldelli-Maia JM, Ventriglio A. The outbreak of COVID-19 coronavirus and its impact on global mental health. Int J Soc Psychiatry. 2020;66(4):317-20.

30. Wu Z, McGoogan JM. Characteristics of and Important Lessons from the Coronavirus Disease 2019 (COVID-19) Outbreak in China: Summary of a Report of 72314 Cases from the Chinese Center for Disease Control and Prevention. J Am Med Assoc. 2020;323(13):1239-42. 
31. Sun P, Lu X, Xu C, Sun W, Pan B. Understanding of COVID-19 based on current evidence. Med Virol.2020;92(6):548-51.

32. Gilat R, Cole BJ. COVID-19, Medicine, and Sports. Arthrosc Sport Med Rehabil. 2020;2(3):e175-6.

33. Corsini A, Bisciotti GN, Eirale C, Volpi P. Football cannot restart soon during the COVID-19 emergency! A critical perspective from the Italian experience and a call for action. $\mathrm{Br} J$ Sports Med.2020;54(20):1186-1187.

34. Rice SM, Gwyther K, Santesteban-Echarri O, Baron D, Gorczynski P, Gouttebarge V, et al. Determinants of anxiety in elite athletes: a systematic review and meta-analysis. $\mathrm{Br} J$ Sports Med.2019;53(11):722-30.

35. Nicholls AR, Polman RCJ, Levy AR, Backhouse SH. Mental toughness in sport: Achievement level, gender, age, experience, and sport type differences. Pers Individ Dif.
2009:47(1):73-5.

36. Marchant DC, Polman RC), Clough PJ, Nicholls AR, Jackson JG, Levy AR. Mental toughness: Managerial and age differences. J Manag Psychol.2009;24(5):428-37.

37. Crust L. Mental toughness in sport: A review. Int J Sport Exerc Psychol. 2007:5(3):270-90.

38. Clough PJ, Earle K, Sewell D. Mental Toughness: The Concept and Its Measurement. In I. Cockerill (Editor). Solutions in Sport Psychology. London: Thomson; 2002. p. 32-43.

39. Horsburgh VA, Schermer JA, Veselka L, Vernon PA. A behavioural genetic study of mental toughness and personality. Pers Individ Dif. 2009;46(2):100-5.

40. Golby J, Sheard M. The relationship between genotype and positive psychological development in national-level swimmers. Eur Psychol. 2006;11(2):143-8. 